\title{
Exploring the Relationship Among Learning Styles, Engagement, and Learning Outcomes in the Context of Role-Play Activities
}

\author{
Jennifer Nicholson \\ Rowan University \\ Pingping Song \\ Georgia Gwinnett College \\ Yide Shen \\ Rowan University \\ Darren Nicholson \\ Rowan University
}

\begin{abstract}
This study proposes a research model to examine whether student engagement during role-play exercises leads to better learning and satisfaction, as well as the influence learning styles have on engagement. Our results confirm that engagement is a multifaceted construct, and show that learning styles affect the dimensions of engagement differently. The effects of each dimension of engagement on student learning and satisfaction also vary. Our research contributes to the theoretical understanding of the relationships among engagement, learning styles, and learning outcomes. Our study also provides practical guidance on how to design instructional activities that accommodate differences in individual learning styles.
\end{abstract}

Keywords: engagement, learning style, learning outcomes, role-play, pedagogy

\section{INTRODUCTION}

Student engagement in the classroom has attracted a lot of interest among educators. Research has found that engagement plays an important role in learning (Carini, Kuh, \& Klein, 2006; Kearsley \& Shneiderman, 1998; Lee, 2014; Zhao \& Kuh, 2004). Increasing evidence has shown that engaging lectures can decrease student distraction, increase students' perceptions of effectiveness of lectures and student confidence in lecture material, as well as improve short-term academic performance and long-term information retention (Miller, McNear, \& Metz, 2013; Steinert \& Snell, 1999; Wilke, 2003).

Although the influence of engagement on student learning outcomes has been extensively studied in the literature, research that examines learning styles and engagement is lacking. Learning styles describe people's preferred ways of learning, and individuals with different learning styles interact with stimuli in the learning context differently (D. A. Kolb, 1976; D. A. Kolb, 1984). Literature has suggested that learning styles have a significant impact on learning performance and learner satisfaction (Backhaus \& Liff, 2007; 
Bostrom, Olfman, \& Sein, 1990; Chou \& Wang, 2000; Eom, Wen, \& Ashill, 2006; Moores, Change, \& Smith, 2004); however, there is limited research on how learning styles impact student engagement in instructional activities.

To explore the effects of engagement on student learning outcomes and the influence of learning styles on engagement, we use role-play, an active learning technique (Freeman, 2003; Kerr, Troth, \& Pickering, 2003), to stimulate student engagement in a classroom setting. Specifically, we examine the effects of learning styles on engagement and whether student engagement during business process role-play exercises leads to better learning and increased satisfaction. By assessing and measuring learning styles, we can better organize and present instructional activities in a way that accommodates different learning styles and ultimately improves learning (Provitera \& Esendal, 2008).

The remainder of this paper is organized as follows. First, we review the literature on engagement and learning styles and develop research hypotheses. Second, we describe the research methodology and present our results. Last, we discuss the potential contributions and limitations of this study.

\section{LITERATURE REVIEW AND HYPOTHESES DEVELOPMENT}

\section{Engagement}

Many studies have found various benefits from student engagement in the classroom, including a positive impact on academic performance and information retention, student confidence with the material, perceived effectiveness of lectures, and a decrease in student distractions during lectures (Dweck, 1986; Lee, 2014; Miller et al., 2013; Steinert \& Snell, 1999; Wilke, 2003). Like Chapman (2003, p. 1), we refer to student engagement as learning task engagement, which encompasses "students' cognitive investment, active participation, and emotional engagement with specific learning tasks."

Fruitful research has been conducted to explore intervention methods faculty can adopt to improve student engagement in classroom activities in an attempt to enhance aspects such as student performance (Collaco, 2017; Francescucci, Kellershohn, \& Pyle, 2021; Sarason \& Banbury, 2004), motivation and interactions between instructors and students (Bogges, Mickel, \& Holton, 2007; Cavanagh, 2011; Herrmann, 2013; Zepke \& Leach, 2010). Active learning is one method that has recently gained a lot of attention in the field of education (Miller \& Metz, 2014). Active learning is concerned with motivating students to engage more meaningfully in both their individual study and class discussion (Herrmann, 2013), rather than just focusing on taking notes. Studies have found that higher levels of student engagement through active learning may encourage a student to accomplish higher-order objectives such as analysis, synthesis, and evaluation (Bonwell \& Eison, 1991).

Researchers also found that in certain settings, students may prefer a traditional lecture over an engaging lecture (e.g., Huang \& Carroll, 1997; Miller et al., 2013). This suggests that the effectiveness of student engagement can vary across settings and that faculty need to take this into consideration when choosing pedagogical methods. Our study uses role-play as the setting to explore the impact of student engagement on learning outcomes.

Role-play has been used in teaching a wide range of disciplines, including: business (Donovan \& Hood, 2021; Taylor Fairbanks, 2018), healthcare (Hamilton et al., 2014; Koch, Ritz, Morrow, Grier, \& McMillianBohler, 2021; Laranjeira, Alfonso, \& Querido, 2021; Shea \& Barney, 2015), education (Leaf et al., 2016; Nurgul, Mehmet, \& Batu, 2014), science (Belova, Eilks, \& Feierabend, 2015; Church, 2021; Namdar \& Namdar, 2021), tourism (Huertas-Valdivia, 2021), law (Tata, 2021), and social science (Pöllänen \& Arjoranta, 2021). Role-play is a type of experiential learning (Lewis \& Williams, 1994) that can make learning tedious topics more enjoyable (Reid, 1985) and stimulate active learning (Freeman, 2003; Kerr et al., 2003). Role-play enables participants to act out a role in a specific situation and immerse themselves in interactions that mimic what they might experience in the real world (Feinstein, Mann, \& Corsun, 2002). This allows participants to become more involved (Broadwell \& Broadwell, 1996), as compared with the traditional instructional methods of lecture and text-based exercises, which will lead to increased learning and higher levels of satisfaction. Thus, we propose the following hypotheses: 


\section{Hypothesis 1: Student engagement in role-play is positively related with student learning}

Hypothesis 2: Student engagement in role-play is positively related with student satisfaction with the learning experience

\section{Learning Style}

Researchers have been interested in finding the underlying motivations that drive engagement and exploring factors or methods that can enhance student engagement (e.g., Dixson, 2010; Lindt \& Miller, 2018; Marx, Simonsen, \& Kitchel, 2016). While there is extensive literature on the impact of learning styles on student learning (e.g., Ashraf, Fendler, \& Shrikhande, 2013; Nicholson, Hamilton, \& McFarland, 2007) and student success (e.g., Goldfinch \& Hughes, 2007), there is very little research on engagement that incorporates learning styles.

Learning style describes "the attitudes and behavior which determine an individual's preferred way of learning" (Honey \& Mumford, 1992). Informed by the growing literature that shows little evidence for learning styles as a valid predictor of academic learning performance (e.g., Knoll, Otani, Skeel, \& Van Horn, 2017; Pashler, McDaniel, Rohrer, \& Bjork, 2009; Rogowsky, Calhoun, \& Tallal, 2015), our study does not propose that learning styles will have a direct impact on student performance and satisfaction. Instead, we are interested in examining the role learning styles play in influencing student engagement in role-play activities, which in turn affects learning outcomes.

In this study, we adopt the typology of learning styles by Honey \& Mumford (1992). Honey and Mumford (1992) suggest that are four learning styles: Activists, Reflectors, Theorists, and Pragmatists. Each of these is described below.

Activists like to learn by doing and are always looking for an activity. They are keen on participating and learn best when working with others in problem solving, games, and role-play exercises. They always look for opportunities to be involved in activities. Reflectors are thoughtful people, who learn by observing and thinking about what happened. They like to stand back, collect data and observe from different perspectives. They prefer to be given an opportunity to review what has happened and take time to think it through thoroughly before coming to a conclusion. Theorists like to understand the theory behind actions. They emphasize logic, conduct analysis and synthesize. They learn best when an activity is backed up by concepts that form a model, theory or system. Pragmatists are practical people and learn best when they see an obvious link between the topic and a current need. Pragmatists also love experimenting and problem solving. They look for new ideas that can solve the problem at hand. Being keen on experimenting, they are eager to try out various ideas and techniques and receive feedback from an expert.

In this research, we use group role-play exercises where students take on the roles of employees from different departments in an organization to coordinate three cross-functional business processes. This setting gives students the opportunity to work with others to complete hands-on tasks, discuss problems, and look for solutions. Students also have the chance to observe how the business processes are carried out from the perspectives of different departments. The role-play activities provide students an opportunity to develop solutions for practical problems related to coordinating common, fundamental business processes across various functional areas. Due to the nature of the group role-play exercises, we expect that individual learners who score high on the Activist, Reflector or Pragmatist learning styles will be more engaged in role-play exercises.

Hypothesis 3: Student's score on the Activist learning style will be positively related to their level of engagement in the role-play activities

Hypothesis 4: Student's score on the Reflector learning style will be positively related to their level of engagement in the role-play activities

Hypothesis 5: Student's score on the Pragmatist learning style will be positively related to their level of engagement in the role-play activities 
Since group role-play exercises involve activities about coordinating cross-functional business processes that are more practical than theoretical, we don't expect there to be a relationship between the Theorist learning style and engagement.

Hypothesis 6: Student's score on the Theorist learning style will not be significantly related to their level of engagement in the role-play activities

Figure 1 shows our research model.

\section{FIGURE 1 RESEARCH MODEL}

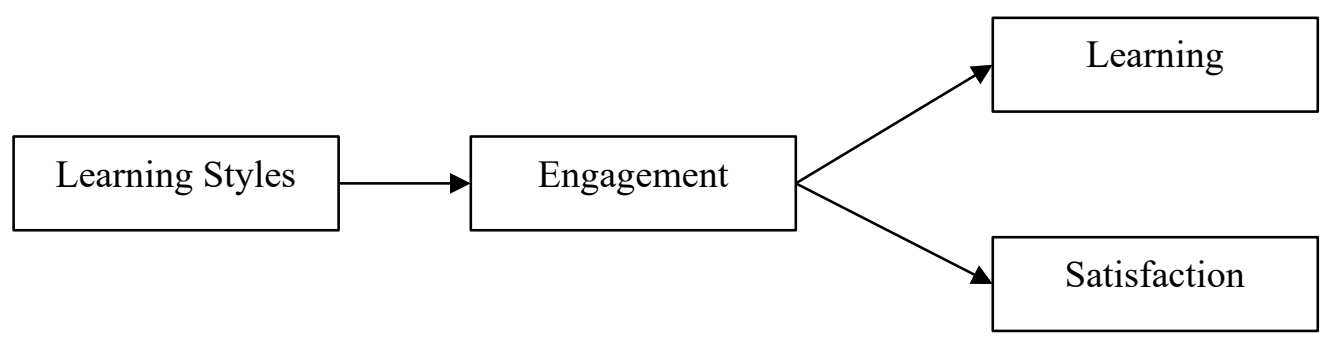

\section{METHODOLOGY}

\section{Research Context}

A survey study was conducted to evaluate our research model. Data was collected from students in three sections of an introductory Management Information Systems (MIS) course at a northeastern US university. The course is a core business course that all business majors are required to take. As a major component of the course, we use a textbook titled Essentials of Business Processes and Information Systems (Magal \& Word, 2009) to teach a five-week module on the topic of using enterprise resource planning (ERP) systems to support business processes.

Three role-play exercises (Shen, Nicholson, \& Nicholson, 2015) are used to actively engage students in learning about the cross-functional nature of business processes and the importance of using an ERP system to complete the steps in a process. Each role-play exercise takes approximately 30-40 minutes and focuses on the steps involved in completing one of three generic business processes - procurement, fulfillment, and production. In each role-play exercise, students form groups of four to five people. A group is given a packet that contains the key documents that are generated from completing the different steps in the process, as well as a list of questions about the process.

Within a group, each student takes on the role of either an employee in a fictitious skateboard company or an external partner (i.e., customer or vendor). Using the textbook and documents provided in the packet, students work together to answer the list of questions while walking through the steps in the business process. By working within their groups, students discover how challenging it is to coordinate with various functional areas and external partners in completing the steps in the business process without the support of an ERP system.

The role-play exercises accommodate different learning styles, such as learning by doing (Activists), problem solving (Pragmatists), and observing and thinking (Reflectors). As such, this setting provides a good opportunity for testing the proposed research model. We administered a pre-activity questionnaire before the first role-play exercise and a post-activity questionnaire after students finished the last role-play exercise. The pre-activity questionnaire contains the instrument to measure learning styles and the postactivity questionnaire contains the instruments to measure the other constructs in our research model. 


\section{Questionnaire Development}

An extensive literature review was conducted to identify measurement scales for all constructs. Whenever possible, we adapted validated measures from previous studies for this research.

\section{Learning Style}

To measure learning styles, we used Honey and Mumford's (1992) Learning Styles Questionnaire (LSQ), which contains 20 statements for each of the four learning styles (i.e., Activist, Reflector, Theorist and Pragmatist) for a total of 80 statements. Respondents were asked to place a tick mark next to a statement if they agreed more than they disagreed with it.

\section{Engagement}

To measure student engagement during role-play exercises, we adapted Wiggins et al.'s (2017) 16-item instrument called Assessing Student Perspective of Engagement in Class Tool (ASPECT). As we focus on students' involvement in the role-play activity, we adopted two out of the three dimensions Wiggins et al. (2017) used: value of activity for learning (VA, Question 1-9) and personal effort put into the activity (PE, Question 10-12). We did not use the third dimension, as it addresses student perceptions of instructor effort put into the activity. Students were asked to rate the extent to which they agreed or disagreed with each of 16 statements, on a scale ranging from 1 to 7, where 1 represents a strong level of disagreement and 7 represents a strong level of agreement.

\section{Learning}

We measured students' perceived learning and actual learning of the three key business processes and the role of ERP systems in supporting those business processes. To measure perceived learning, we adapted ten questions from Seethamraju (2007). Students were asked to self-assess their knowledge about the three key business processes before and after participating in the role-play exercises. The self-assessment scale ranges from 1 to 7 , where 1 represents a very low level of knowledge and 7 represents a very high level of knowledge. We calculated the difference between self-assessment scores before and after learning, and used it to measure perceived learning. Actual learning was measured by using students' performance on 19 exam questions (by taking the ratio of correctly answered questions) that mapped to the primary learning objectives of the three business processes.

\section{Satisfaction}

We used two instruments to measure student satisfaction. We adapted eight questions from Kerr (2003) and Costain and McKenna (2011) that asked students to rate their satisfaction with the role-play activity itself (SA1). In addition, students were asked five questions on how they would rate their satisfaction with using the role-play exercises to learn about business processes (SA2). Students were asked to rate the extent to which they agreed or disagreed with each of the 13 statements on a scale ranging from 1 to 7 , where 1 represents a strong level of disagreement and 7 represents a strong level of agreement.

\section{DATA ANALYSIS AND RESULTS}

\section{Participants, Measurement Reliability and Descriptive Statistics}

Out of the ninety-five students who participated in this research study, three participants were removed from the sample due to incomplete data, leaving a final sample size of ninety-two.

We calculated Cronbach's alpha values for all multi-item measures to check measurement reliability. For the two engagement dimensions, value of activity for learning (VA) and personal effort put into the activity (PE), the Cronbach's alpha values were 0.92 and 0.86 , respectively. For learning, the scale's Cronbach's alpha value was 0.96 . For the two satisfaction measures, satisfaction with the role-play activity itself (SA1) and satisfaction with using the role-play exercises to learn about business processes (SA2), the Cronbach's alpha values were 0.94 and 0.91 , respectively. These values all exceed the 0.70 threshold (Nunnally, 1978), which shows high reliability for our measures. 
All the questions on the survey were on a 7-point Likert scale, except for the learning style questions. Each learning style was measured by the student's response on the 20 statements associated with that learning style. Table 1 shows the descriptive statistics for the various constructs and inter-construct correlations.

TABLE 1

DESCRIPTIVE STATISTICS AND CORRELATIONS

\begin{tabular}{|l|l|l|l|l|l|l|l|l|l|l|l|l|}
\hline & Mean & SD & Activist & Reflector & Theorist & Pragmatist & VA & PE & AL & PL & SA1 & SA2 \\
\hline Activist & 8.22 & 3.56 & 1 & & & & & & & & & \\
\hline Reflector & 12.33 & 3.18 & -0.116 & 1 & & & & & & & & \\
\hline Theorist & 10.27 & 3.37 & -0.106 & $0.365^{*}$ & 1 & & & & & & & \\
\hline Pragmatist & 10.78 & 3.09 & 0.174 & $0.208^{*}$ & $0.549^{*}$ & 1 & & & & & & \\
\hline VA & 5.08 & 1.10 & $0.194^{*}$ & 0.118 & -0.018 & 0.056 & 1 & & & & & \\
\hline PE & 5.39 & 1.14 & -0.035 & $0.236^{*}$ & -0.003 & 0.029 & $0.6805^{*}$ & 1 & & & & \\
\hline AL & 0.73 & 0.15 & $-0.242^{*}$ & -0.008 & 0.041 & -0.037 & 0.112 & 0.167 & 1 & & & \\
\hline PL & 3.48 & 1.19 & 0.014 & -0.027 & -0.142 & $-0.228^{*}$ & $0.315^{*}$ & $0.251^{*}$ & 0.145 & 1 & & \\
\hline SA1 & 5.20 & 1.22 & 0.127 & $0.235^{*}$ & 0.117 & 0.056 & $0.891^{*}$ & $0.711^{*}$ & 0.136 & $0.325^{*}$ & 1 & 1 \\
\hline SA2 & 5.32 & 1.16 & 0.164 & 0.139 & -0.040 & -0.058 & $0.776^{*}$ & $0.617^{*}$ & 0.086 & $0.297^{*}$ & $.821^{*}$ & 1 \\
\hline
\end{tabular}

* Significant at 0.05

VA: Engagement - value of activity

PE: Engagement - personal effort

AL: Actual learning

PL: Perceived learning

SA1: Satisfaction with the role-play activity itself

SA2: Satisfaction with using the role-play activity to learn about business processes

\section{Hypotheses Testing}

We used regression to test the hypotheses in our research model. Table 2 summarizes the results for hypotheses 1-6. The rest of this section presents results for each hypothesis.

TABLE 2

\section{SUMMARY OF HYPOTHESIS TESTING}

\begin{tabular}{|l|l|l|}
\hline \multicolumn{2}{|l|}{ Hypothesis } & Supported? \\
\hline H1 & Engagement $\rightarrow$ Learning $(+)$ & Partial \\
\hline H2 & Engagement $\rightarrow$ Satisfaction $(+)$ & Yes \\
\hline H3 & Activist learning style $\rightarrow$ Engagement $(+)$ & Partial \\
\hline H4 & Reflector learning style $\rightarrow$ Engagement $(+)$ & Partial \\
\hline H5 & Pragmatist learning style $\rightarrow$ Engagement $(+)$ & No \\
\hline H6 & Theorist learning style $\rightarrow$ Engagement $($ no impact) & Yes \\
\hline
\end{tabular}

Figure 2 summarizes the results for H1, which hypothesizes the effect of engagement on learning in our research model. Of the two engagement dimensions, value of activity (VA) and personal effort (PE), VA was significantly related to perceived learning, but PE was not. Interestingly, PE was significantly related to actual learning, but VA was not. Thus, H1 is partially supported. 
FIGURE 2

HYPOTHESIS TESTING RESULTS (H1)

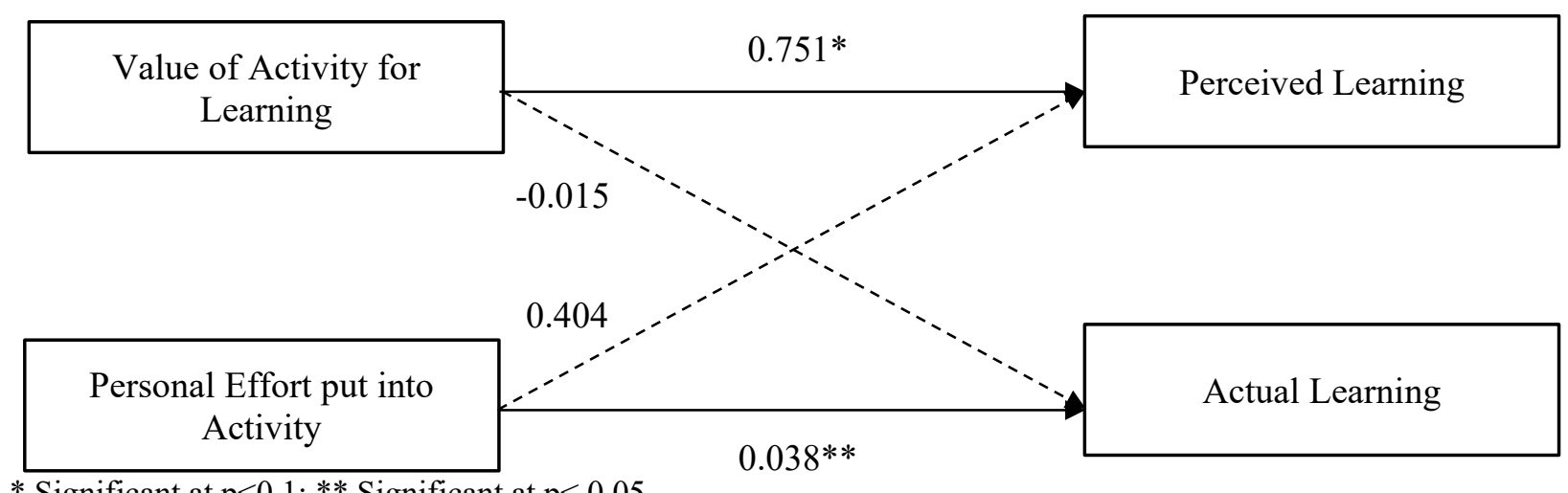

* Significant at $\mathrm{p}<0.1 ; * *$ Significant at $\mathrm{p}<0.05$

As shown in Figure 3, H2 is supported. Both engagement dimensions (VA and PE) were significantly positively related to satisfaction with the role-play activity itself (SA1) and satisfaction with using role-play to learn about business processes (SA2).

FIGURE 3

HYPOTHESIS TESTING RESULTS (H2)

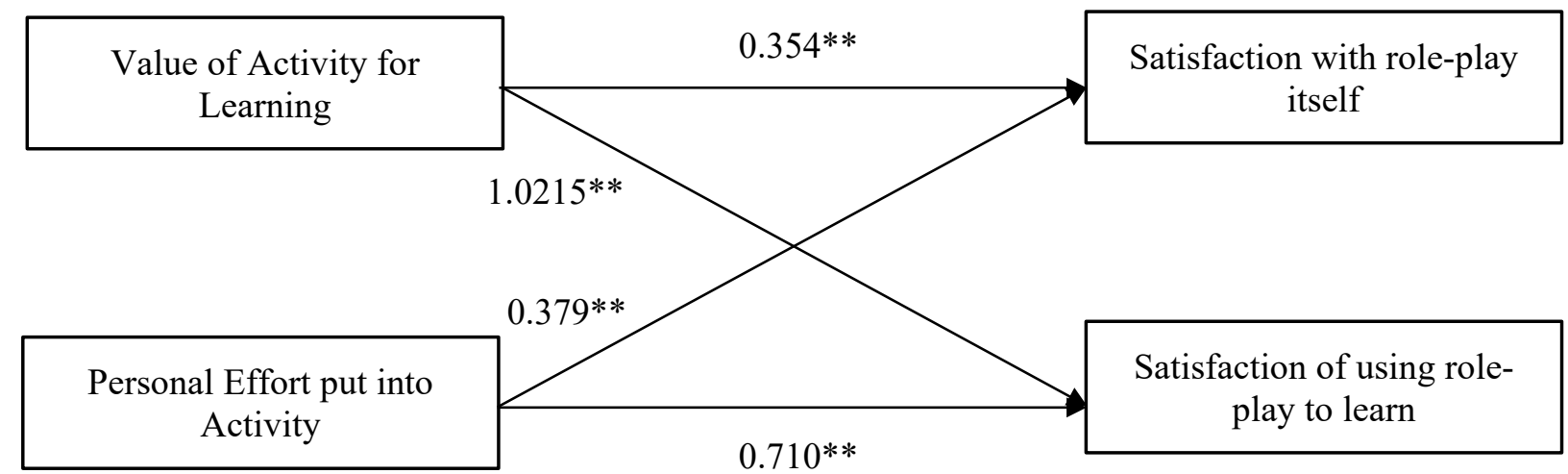

* Significant at $\mathrm{p}<0.1 ; * *$ Significant at $\mathrm{p}<0.05$

Table 3 summarizes the regression results of the two engagement dimensions on learning and on satisfaction (H1 and $\mathrm{H} 2)$.

TABLE 3

REGRESSION RESULTS:

STUDENT ENGAGEMENT, LEARNING, AND SATISFACTION (H1-2)

\begin{tabular}{|l|l|l|l|l|}
\hline & Actual Learning & Perceived Learning & Satisfaction 1 & Satisfaction 2 \\
\hline Engagement (VA) & -0.015 & $0.751 *$ & $0.354^{* *}$ & $1.215^{* *}$ \\
\hline Engagement (PE) & $0.039^{*}$ & 0.404 & $0.379 * *$ & $0.710^{* *}$ \\
\hline R-squared & 0.041 & 0.110 & 0.371 & 0.564 \\
\hline
\end{tabular}

* Significant at $\mathrm{p}<0.1 ; * *$ Significant at $\mathrm{p}<0.05$ 
Figure 4 summarizes the results for $\mathrm{H} 3$ to $\mathrm{H} 6$, which hypothesize the effect of learning styles on engagement in our research model.

\section{HYPOTHESES TESTING RESULTS}

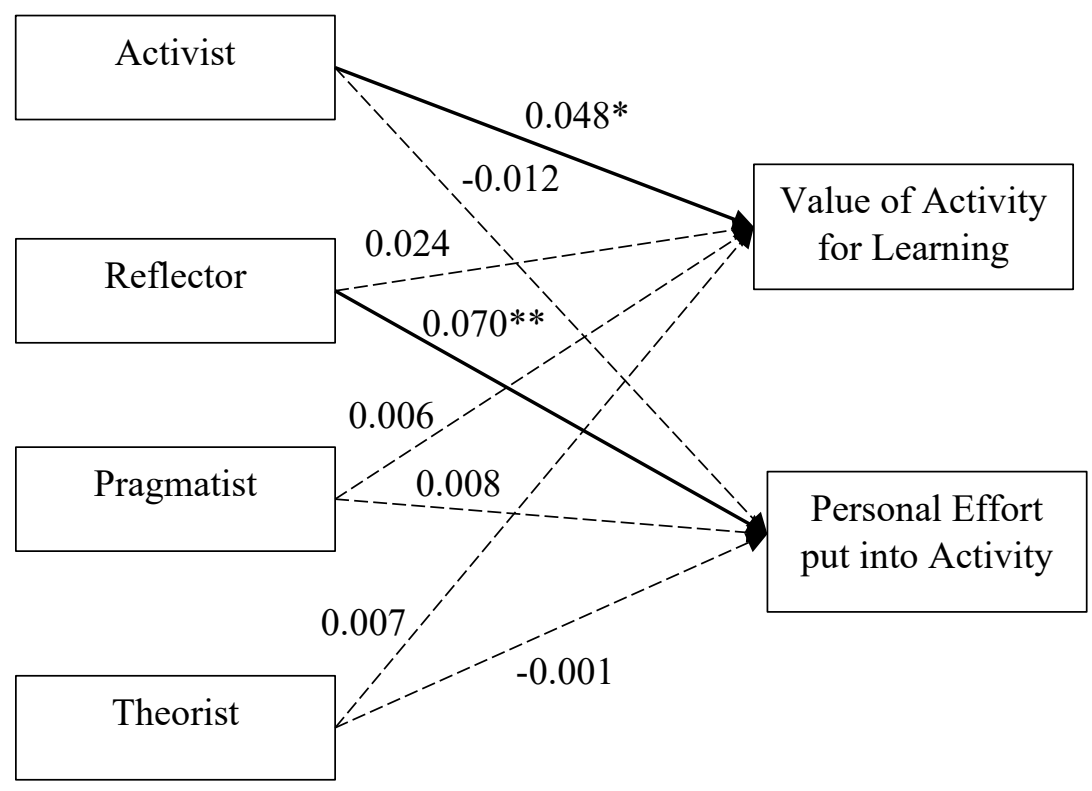

* Significant at $\mathrm{p}<0.1 ; *$ Significant at $\mathrm{p}<0.05$

Tables 4 through 6 show the regression results of each learning style on the two dimensions of engagement. As shown in Table 4, a higher score on the Activist learning style was found to be related to higher value of activity, suggesting that learners with high Activist scores tend to appreciate the experiential learning activity of role-play to a greater degree. However, no significance was found for personal effort. Thus, $\mathrm{H} 3$ is partially supported.

TABLE 4

REGRESSION RESULTS: ACTIVIST LEARNING STYLE AND ENGAGEMENT (H3)

\begin{tabular}{|l|l|l|}
\hline Learning Style & $\begin{array}{l}\text { Engagement } \\
\text { Value of Activity }\end{array}$ & $\begin{array}{l}\text { Engagement } \\
\text { Personal Effort }\end{array}$ \\
\hline Activist & $0.048^{*}$ & -0.012 \\
\hline R-squared & 0.040 & 0.002 \\
\hline
\end{tabular}

* Significant at $\mathrm{p}<0.1 ; * *$ Significant at $\mathrm{p}<0.05$

As shown in Table 5, H4 is also partially supported, as a higher score on the Reflector learning style was positively related to the personal effort dimension of engagement, but not the value of the activity dimension, suggesting that learners with high Reflector scores spend more effort on the role-play activities. 
TABLE 5

REGRESSION RESULTS: REFLECTOR LEARNING STYLE AND ENGAGEMENT (H4)

\begin{tabular}{|l|l|l|}
\hline Learning Style & $\begin{array}{l}\text { Engagement } \\
\text { Value of Activity }\end{array}$ & $\begin{array}{l}\text { Engagement } \\
\text { Personal Effort }\end{array}$ \\
\hline Reflector & 0.024 & $0.070^{* *}$ \\
\hline R-squared & 0.008 & 0.059 \\
\hline
\end{tabular}

* Significant at $\mathrm{p}<0.1 ; * *$ Significant at $\mathrm{p}<0.05$

As presented in Table 6, no significance was found between the Pragmatist learning style and engagement, thus $\mathrm{H} 5$ is not supported.

TABLE 6

REGRESSION RESULTS: PRAGMATIST LEARNING STYLE AND ENGAGEMENT (H5)

\begin{tabular}{|l|l|l|}
\hline Learning Style & $\begin{array}{l}\text { Engagement } \\
\text { Value of Activity }\end{array}$ & $\begin{array}{l}\text { Engagement } \\
\text { Personal Effort }\end{array}$ \\
\hline Pragmatist & 0.006 & 0.008 \\
\hline R-squared & 0.000 & 0.001 \\
\hline
\end{tabular}

* Significant at $\mathrm{p}<0.1 ; * *$ Significant at $\mathrm{p}<0.05$

The results are consistent with H6, showing no significant relationship between the Theorist learning style and value of activity or personal effort, suggesting that high Theorist scores are not necessarily related to higher levels of engagement. Thus, H6 is supported, as shown in Table 7.

TABLE 7

REGRESSION RESULTS: THEORIST LEARNING STYLE AND ENGAGEMENT (H6)

\begin{tabular}{|l|l|l|}
\hline Learning Style & $\begin{array}{l}\text { Engagement } \\
\text { Value of Activity }\end{array}$ & $\begin{array}{l}\text { Engagement } \\
\text { Personal Effort }\end{array}$ \\
\hline Theorist & 0.007 & -0.001 \\
\hline R-squared & 0.001 & 0.000 \\
\hline
\end{tabular}

* Significant at $\mathrm{p}<0.1 ; * *$ Significant at $\mathrm{p}<0.05$

\section{DISCUSSION}

In this study, we presented and tested a research model to examine the role that learning styles play in influencing engagement, and the effect that engagement has on learning and satisfaction. We discuss the findings for each of our hypothesized relationships below.

\section{Engagement and Learning/Satisfaction}

We hypothesized that engagement would be positively related to learning and satisfaction. To measure student engagement, we adopted two dimensions from Wiggins et. al. (2017): value of activity for learning and personal effort put into the activity. Both dimensions of engagement - value of activity (VA) and personal effort (PE) - had a significant positive impact on learning. However, each of them was significantly related to only one aspect of learning. Specifically, higher VA led to higher levels of perceived learning, while higher PE led to higher levels of actual learning. A potential interpretation is that when students think of a learning activity as valuable and useful, they develop a higher level of interest in the learning activity, and they perceive the learning experience and outcome as being more valuable and useful. However, this 
does not necessarily lead to a higher investment in learning. Therefore, no significant impact on actual learning was found in our study. In other words, the value impact on perceived learning is more about perception, but not necessarily on actual learning achieved. The personal effort put into learning, however, increased actual learning but not perceived learning. This implies that while students made gains in actual learning, they did not realize the learning they achieved.

Both dimensions of engagement - value of activity and personal effort - were also found to have a significantly positive impact on satisfaction with the role play itself as well as with the learning experience. This suggests the importance of promoting both dimensions of engagement to improve student satisfaction with learning activities. It is therefore worthwhile for instructors to spend time helping students recognize the value of the learning activity and urging students to put sufficient time and effort into the activity.

\section{Learning Styles and Engagement}

We hypothesized that all learning styles, with the exception of Theorist, would be positively related to student engagement in the role-play exercise. Our results are consistent with the hypothesis that there is no relationship between the Theorist learning style and engagement. In addition, we found partial support for the relationship between the Activist and Reflector learning styles and engagement, but no support for the Pragmatist learning style. We elaborate on these findings below as they relate to the two dimensions of engagement.

While the Activist learning style was positively related to the value of the role-play activity, it was not positively related to personal effort put into the activity. The opposite was found to be true for the Reflector learning style. Activists always look for opportunities to be involved in an activity and learn best through this involvement. Since the items used to measure value of an activity are related to collaborating with, and learning from, others, it makes sense that there is support for the relationship between the Activist learning style and value of the activity. We believe, however, that just because someone values an activity does not necessarily mean they feel as if they have to put a lot of effort into the activity. For Activists, this seems to be the case. Reflectors are different from Activists in that they typically prefer to stand back and watch and learn as they go. While the role-play activity allowed students to observe how cross-functional business processes are carried out from multiple functional areas' perspectives, it did not allow much time for students to stand back and reflect before drawing conclusions. Rather, the activity required students to jump in right away and actively participate. Because this is against the very nature of Reflectors, it may have seemed that the activity required more effort to complete than what might come naturally for them. This may have also influenced their perception towards the value of the activity -- again because Reflectors learn by observing not necessarily by collaborating with others.

As hypothesized, there was no significant relationship between the Theorist learning style and engagement. Contrary to our hypothesis, the same was true for the Pragmatist. Those with the Pragmatist learning style learn best when they see a link between the topic and a current need. It is possible that the Pragmatists did not see the relevance between the role-play activity and real-world challenges that they could face, and therefore devalued the activity. In addition, Pragmatists like to experiment and get feedback from experts. However, the role-play activity was highly structured and explicit and not conducive to experimentation or feedback from experts. As such, those students that scored high on the Pragmatist learning style may not have perceived the activity to have much value or require much personal effort. While the instructor overseeing the activity was an expert who went into a detailed explanation after the role-play exercise, the Pragmatist might have experienced a greater sense of engagement if the instructor was more involved during the role-play exercise.

\section{CONCLUSION}

In this paper, we proposed and tested a research model to examine whether student engagement during role-play exercises leads to better learning and satisfaction, and the effects of learning styles on engagement.

Our results reinforce prior research that found engagement to be a multifaceted construct (Christenson, Reschly, \& Wylie, 2012; Reeve \& Lee, 2014). Moreover, our results show that learning styles affect the 
two dimensions of engagement differently. The effects of each dimension of engagement, i.e., value of activity for learning and personal effort put into activity, on student learning and satisfaction also varied.

Our results have many implications for researchers and practitioners. By looking at engagement as a multi-dimensional construct, we were able to differentiate between dimensions of engagement with which individual learning styles most closely align in the context of our role-play activity. These results suggest that the techniques employed during the learning activity may need to better align with various learning styles in order to improve student engagement. For example, to try to improve the level of engagement for the Pragmatist, the activity could provide more opportunities for experimentation and feedback from an expert (possibly the faculty member).

Our study also found that each dimension of engagement had different effects on perceived learning and actual learning. Specifically, we found that higher activity value led to higher levels of perceived learning, while higher personal effort put into an activity led to higher actual learning. Further research could look at what situational factors may lead to this inconsistency: when and why the inconsistency happens, and under what circumstances this inconsistency is particularly distinct. Moreover, discretion should be used when examining learning results and interpretations should be carefully made: perceived learning may not accurately reflect actual learning achieved and thus should not be used as the only measure for learning. This inconsistency should also be considered in the assessment of learning or pedagogy: students may have achieved learning but don't realize it, thus they may not give adequate credit to the effectiveness of instructors and their pedagogy. From the perspective of educators, in addition to a commitment to help students learn, it is also worthwhile to have students recognize the value of the learning activity or teaching techniques employed so that they will perceive their learning as fruitful. Also, students' actual learning should be considered when measuring the effectiveness of instructors and their pedagogy.

Future research could also explore other dimensions of engagement that were not captured in our study, such as cognitive and emotional engagement (Morgan-Thomas \& Dudau, 2019; Taylor \& Statler, 2014), and examine their relationship with learning styles and learning performance. Additionally, given the observed difference between perceived learning and actual learning, the relationship between learning performance and satisfaction could be further examined. Do students with higher perceived or achieved learning feel more satisfied with the learning activity and the learning experience?

As is the case with all research, our study has some limitations. First, the research model in this study was evaluated using simple regression analysis only and the observed effect sizes for the learning styles were relatively small. Second, this study focused on individual-level constructs and their relationships, while studies have shown that the learning style profile of teams impacts group work and learning (Erdem, 2009; Soetanto \& MacDonald, 2017). Hence, future research could also explore the influence of team learning style composition on student engagement and learning.

\section{REFERENCES}

Ashraf, R., Fendler, R., \& Shrikhande, M. (2013). Impact of Personality and Learning styles on Performance. Journal of Financial Education, 39(3/4), 47-68.

Backhaus, K., \& Liff, J.P. (2007). Cognitive Styles and Approaches to Studying in Management Education. Journal of Management Education, 31(4), 445-466.

Belova, N., Eilks, I., \& Feierabend, T. (2015). THE EVALUATION OF ROLE-PLAYING IN THE CONTEXT OF TEACHING CLIMATE CHANGE. International journal of science and mathematics education, 13(S1), 165-190. doi:10.1007/s10763-013-9477-x

Bogges, J.G., Mickel, A.E., \& Holton, B.C. (2007). Experiential Learning Through Interactive Drama: An Alternative to Student Role Plays. Journal of Management Education, 31(6), 832-858.

Bonwell, C.C., \& Eison, J.A. (1991). Active learning: Creating excitement in the classroom. Washington, DC: George Washington University.

Bostrom, R., Olfman, L., \& Sein, M. (1990). The importance of learning style in end-user training. MIS Quarterly, 14(1), 101-119. 
Broadwell, M.M., \& Broadwell, D.C. (1996). How to Get Trainees into the Action. Training, 33(2), 5256.

Carini, R.M., Kuh, G.D., \& Klein, S.P. (2006). Student engagement and student learning: Testing the linkages. Research in Higher Education, 47(1), 1-32.

Cavanagh, M. (2011). Students' experiences of active engagement through cooperative learning activities in lectures. Active Learning in Higher Education, 12(1), 23-33.

Chapman, E. (2003). Alternative approaches to assessing student engagement rates. Practical Assessment, $8(13), 1-7$.

Chou, H.W., \& Wang, T.B. (2000). The influence of learning style and training method on self-efficacy and learning performance in WWW homepage design training. International Journal of Information Management, 20(6), 455-472.

Christenson, S.L., Reschly, A.L., \& Wylie, C. (2012). Handbook of Research on Student Engagement. New York: Springer Science.

Church, F.C. (2021). Active Learning: Basic Science Workshops, Clinical Science Cases, and Medical Role-Playing in an Undergraduate Biology Course. Education Sciences, 11(370), 370. doi:10.3390/educsci11080370

Collaco, C.M. (2017). Increasing Student Engagement in Higher Education. Journal of Higher Education Theory and Practice, 17(4), 40-47.

Costain, G., \& McKenna, B. (2011). Experiencing the Elicitation of User Requirements and Recording them in Use Case Diagrams through Role-Play. Journal of Information Systems Education, 22(4), 367-380.

Dixson, M.D. (2010). Creating effective student engagement in online courses: What do students find engaging? Journal of the Scholarship of Teaching and Learning, 10(2), 1-13.

Donovan, P., \& Hood, A. (2021). Experiential Learning in the Large Classroom Using Performative Pedagogy. Journal of Management Education, 45(3), 340-343.

Dweck, C.S. (1986). Motivational processes affecting learning. American Psychologist, 41(10), 10401048.

Eom, S., Wen, H.J., \& Ashill, N. (2006). The determinants of students' perceived learning outcomes and satisfaction in university online education: An empirical investigation. Decision Sciences Journal of Innovative Education, 4(2), 215-235.

Erdem, M. (2009). Effects of Learning Style Profile of Team on Quality of Materials Developed in Collaborative Learning Processes. Active Learning in Higher Education, 10(2), 154-171.

Feinstein, A.H., Mann, S., \& Corsun, D.L. (2002). Charting the Experiential Territory. Journal of Management Development, 21(10), 732-744.

Francescucci, A., Kellershohn, J., \& Pyle, M.A. (2021). Using Online Class Preparedness Tools to Improve Student Performance: The Benefit of "All-In" Engagement. Journal of Management Education, 45(4), 558-578.

Freeman, L.A. (2003). Simulation and Role Playing with LEGO(R) Blocks. Journal of Information Systems Education, 14(2), 137-144.

Goldfinch, J., \& Hughes, M. (2007). Skills, learning styles and success of first-year undergraduates. Active Learning in Higher Education, 8(3), 259-273.

Hamilton, G., Ortega, R., Hochstetler, V., Pierson, K., Lin, P., \& Lowes, S. (2014). Teaching Communication Skills to Hospice Teams: Comparing the Effectiveness of a Communication Skills Laboratory With In-Person, Second Life, and Phone Role-Playing. American Journal of Hospice \& Palliative Medicine, 31(6), 611-618. doi:10.1177/1049909113504481

Herrmann, K.J. (2013). The impact of cooperative learning on student engagement: Results from an intervention. Active Learning in Higher Education, 14, 175-187.

Honey, P., \& Mumford, A. (1992). The Manual of Learning Styles (3rd Edition ed.). Mainhead, UK.: Peter Honey Publications.

Huang, A.H., \& Carroll, R.G. (1997). Incorporating active learning into a traditional curriculum. American Journal of Physiology, 273(18), S14-S23. 
Huertas-Valdivia, I. (2021). Role-Playing a staffing process: Experiential learning with undergraduate tourism students. The Journal of Hospitality, Leisure, Sport \& Tourism Education, 29. doi:10.1016/j.jhlste.2021.100334

Kearsley, G., \& Shneiderman, B. (1998). Engagement theory: A framework for technology-based teaching and learning. Educational Technology, 38(5), 20-23.

Kerr, D., Troth, A., \& Pickering, A. (2003). The Use of Role-playing to Help Students Understand Information Systems Case Studies. Journal of Information Systems Education, 14(2), 167-171.

Knoll, A.R., Otani, H., Skeel, R.L., \& Van Horn, K.R. (2017). Learning style, Judgement of Learning, and Learning of Verbal and Visual Information. British Journal of Psychology, 108(3), 544-563.

Koch, A., Ritz, M., Morrow, A., Grier, K., \& McMillian-Bohler, J.M. (2021). Role-play simulation to teach nursing students how to provide culturally sensitive care to transgender patients. Nurse education in practice, 54, 103123-103123. doi:10.1016/j.nepr.2021.103123

Kolb, D.A. (1976). Learning Style Inventory: Technical manual. Boston: McBer.

Kolb, D.A. (1984). Experiential learning: Experience as the source of learning and development. New Jersey: Prentice-Hall.

Laranjeira, C., Alfonso, C., \& Querido, A. (2021). Communicating Bad News: Using Role-Play to Teach Nursing Students. SAGE Open Nursing, 7. doi:10.1177/23779608211044589

Leaf, J.B., Taubman, M., Milne, C., Dale, S., Leaf, J., Townley-Cochran, D., . . McEachin, J. (2016). Teaching Social Communication Skills Using a Cool Versus Not Cool Procedure Plus RolePlaying and a Social Skills Taxonomy. Education \& Treatment of Children, 39(1), 44-63.

Lee, J.S. (2014). The relationship between student engagement and academic performance: Is it a myth or reality? Journal of Educational Research, 107(3), 177-185.

Lewis, L.H., \& Williams, C.J. (1994). Experiential Learning: Past and Present. New Directions for Adult and Continuing Education, (62), 5-16.

Lindt, S.F., \& Miller, S.C. (2018). Understanding Factors Leading to College Classroom Engagement for Millennials: Development of the College Classroom Engagement Scale. Higher Education Research, 3(3), 38-44.

Magal, S.R., \& Word, J. (2009). Essentials of Business Processes and Information Systems (1st edition ed.). Wiley.

Marx, A.A., Simonsen, J.C., \& Kitchel, T. (2016). Undergraduate Student Course Engagement and the Influence of Student, Contextual, and Teacher Variables. Journal of Agricultural Education, $57(1), 212-228$.

Miller, C.J., McNear, J., \& Metz, M.J. (2013). A comparison of traditional and engaging lecture methods in a large, professional-level course. Advances in Physiology Education, 37, 347-355.

Miller, C.J., \& Metz, M.J. (2014). A comparison of professional-level faculty and student perceptions of active learning: Its current use, effectiveness, and barriers. Advances in Physiology Education, 38, 246-252.

Moores, T., Change, J., \& Smith, D. (2004). Learning style and performance: A field study of IS students in an analysis and design course. Journal of Computer Information Systems, 45(1), 77-85.

Morgan-Thomas, A., \& Dudau, A. (2019). Of Possums, Hogs, and Horses: Capturing the Duality of Student Engagement in e-learning. Academy of Management Learning \& Education, 18(4), 564580.

Namdar, B., \& Namdar, A.O. (2021). Fostering Students' Values Through Role Play about Socioscientific Issues. The Physics Teacher, 59(6), 497-499. doi:10.1119/5.0019320

Nicholson, D., Hamilton, D., \& McFarland, D. (2007). Leveraging Learning Styles to Improve Student Learning: The interactive learning model and learning combination inventory. Journal of Computing Sciences in Colleges, 22(6), 8-17.

Nunnally, J.C. (1978). Psychometric Theory (2nd ed. ed.). New York: McGraw-Hill.

Nurgul, A., Mehmet, Y., \& Batu, E.S. (2014). Comparing Video Modeling and Graduated Guidance together and Video Modeling alone for Teaching Role Playing Skills to Children with Autism. Education and Training in Autism and Developmental Disabilities, 49(1), 17-31. 
Pashler, H., McDaniel, M., Rohrer, D., \& Bjork, R. (2009). Learning Styles: Concepts and Evidence. Psychological Science in the Public Interest, 9(3), 105-119.

Pöllänen, S., \& Arjoranta, J. (2021). 'Whose were those feelings?' Affect and likenessing in Halat hisar live action role-playing game. International Journal of Cultural Studies, 136787792110235. doi:10.1177/13678779211023520

Provitera, M.J., \& Esendal, E. (2008). Learning and Teaching Styles in Management Education: Identifying, Analyzing, and Facilitating. Journal of College Teaching \& Learning, 5(1), 69-77.

Reeve, J., \& Lee, W. (2014). Students' Classroom Engagement Produces Longitudinal Changes in Classroom Motivation. Journal of Educational Psychology, 106, 527-540.

Reid, G. (1985). Accelerated Learning: Technical Training Can Be Fun. Training and Development Journal, 39(9), 24.

Rogowsky, B.A., Calhoun, B.M., \& Tallal, P. (2015). Matching Learning Styles to Instructional Methods: Effects on Comprehension. Journal of Educational Psychology, 107(1), 64-78.

Sarason, Y., \& Banbury, C. (2004). Active Learning Facilitated by Using a Game-show Format or Who Doesn't Want to be a Millionaire? Journal of Management Education, 28(4), 509-518.

Seethamraju, R. (2007). Enterprise Systems (ES) Software in Business School Curriculum - Evaluation of Design and Delivery. Journal of Information Systems Education, 18(1), 69-83.

Shea, S.C., \& Barney, C. (2015). Teaching clinical interviewing skills using role-playing: Conveying empathy to performing a suicide assessment: a primer for individual role-playing and scripted group role-playing. The Psychiatric Clinics of North America, 38(1), 147-183. doi:10.1016/j.psc.2014.10.001

Shen, Y., Nicholson, J., \& Nicholson, D. (2015). Using a Group Role-Play Exercise to Engage Students in Learning Business Processes and ERP. Journal of Information Systems Education, 26(4), 265 280.

Soetanto, D., \& MacDonald, M. (2017). Group Work and the Change of Obstacles Over Time: The Influence of Learning Style and Group Composition. Active Learning in Higher Education, 18(2), 99-113.

Steinert, Y., \& Snell, L.S. (1999). Interactive lecturing: Strategies for increasing participation in large group presentations. Medical Teacher, 21, 37-42.

Tata, M.A. (2021). The Pleasure of the Contract: Legal Role Play from Leopold von Sacher-Masoch Through Noodles \& Beef. Golden Gate University Law Review, 51(2), 147.

Taylor Fairbanks, V. (2018). Afraid of the Deep: Reflections and Analysis of a Role-Play Exercise Gone Wrong. Journal of Management Education, 42(6), 772-782.

Taylor, S.S., \& Statler, M. (2014). Material Matters: Increasing Emotional Engagement in Learning. Journal of Management Education, 38(4), 586-607.

Wiggins, B.L., Eddy, S.L., Wener-Fligner, L., Freisem, K., Grunspan, D.Z., Theobald, E.J., Timbrook, J., \& Crowe, A.J. (2017). ASPECT: A Survey to Assess Student Perspective of Engagement in an Active-Learning Classroom. CBE-Life Sciences Education, 16(2).

Wilke, R.R. (2003). The effect of active learning on student characteristics in a human physiology course for non-majors. Advances in Physiology Education, 27, 207-223.

Zepke, N., \& Leach, L. (2010). Improving Student Engagement: Ten Proposals for Action. Active Learning in Higher Education, 11(3), 167-177.

Zhao, C.M., \& Kuh, G.D. (2004). Adding value: Learning communities and student engagement. Research in Higher Education, 45, 115-138. 